\title{
COVID-19, karantinas ir miego sutrikimai: literatūros apžvalga
}

\begin{abstract}
E. Sakalauskaitė-Juodeikienẻ Santrauka. Jau senoveje žinota, kad poilsis ir miegas yra gyvybiškai svarbūs, tokie pat reikšmingi kaip kvėpavimas, valgymas ir kitos organizmo funkcijos. Per pastaruosius 30 metų nustatyta aiški sąsaja tarp pakankamo, kokybiško miego ir darnaus imuninės sistemos funkcionavimo. Šiame straipsnyje apžvelgsiu virusinės infekcijos sukeliamus miego pokyčius ir pateiksiu įrodymų, kad miego trūkumas veikia kaip reikšmingas funkcinę imunosupresiją sukeliantis faktorius. Taip pat apžvelgsiu naujausią mokslinę literatūrą, kurioje pastaruoju metu skelbiama, kad melatonino ar melatonino receptorių agonistų skyrimas ligoniams, gydomiems reanimacijos ir intensyviosios terapijos skyriuose dèl COVID-19, gali pagerinti šių ligonių miegą, sumažinti ūmių sąmonès sutrikimų išsivystymo riziką ir apsaugoti ligonius nuo „citokinų audros“ bei tolesnio kvèpavimo sistemos pažeidimo. Galiausiai bus išaiškinta, kaip kokybiškas, pakankamas miegas ir miego higienos rekomendacijų laikymasis šioje sudètingoje situacijoje gali būti vienas svarbiausių veiksnių, reguliuojančių mūsų elgesį, emocijas ir lemiančių tinkamas imuninès sistemos funkcijas.
\end{abstract}

Raktažodžiai: miego sutrikimai, virusinè infekcija, ūmios fazės atsakas, COVID-19, melatoninas.

\section{IVADAS}

Daugelis sergančiųų infekcinėmis ligomis yra patyrę tipiškus simptomus - energijos stoką, bendrą kūno diskomfortą ir mieguistumą. Ūmiai susirgę ligoniai dažniausiai išgirsta tokị patarimą iš artimųjų ir gydytojų: išsigulèk, išsimiegok, kad greičiau pasveiktum ir neatkristum. Šis įsitikinimas - senas kaip pasaulis. Tiek liaudies medikai, tiek Antikos išminčiai Hipokratas (apie 460-360 m. pr. Kr.) ir Aristotelis (384-322 m. pr. Kr.) pripažino, kad miegant žmogaus organizmas efektyviau kovoja su liga.

Monpeljè universiteto auklètinis Žanas Emanuelis Žiliberas (1741-1814) veikiausiai buvo pirmasis, skleidęs gyvybinių galių (vitalizmo) doktrinos principus Abiejų Tautų Respublikos (ATR) žemèse. Ž. E. Žiliberas 1775 m. buvo pakviestas į Gardiną dèstyti Karališkojoje medicinos mokykloje, kurią likvidavus, mokslininkas 1781 m. persi-

\author{
Adresas: \\ Eglè Sakalauskaité-Juodeikiené \\ Vilniaus universiteto ligoninès Santaros kliniku \\ Neurologijos centras \\ Santariškiu g. 2, LT-08661 Vilnius \\ El. paštas egle.sakalauskaite-juodeikiene2@santa.lt
}

kèlè ị Vilnių ir tapo Vilniaus universiteto Gamtos istorijos katedros profesoriumi (1781-1783) [1]. Vèlesniame veikale Histoire des plantes d'Europe et étrangères, les plus communes les plus utiles et les plus curieuses, ou Élémens de botanique pratique („Labiausiai paplitusių, naudingiausių ir keisčiausių Europos ir užsienio šalių augalų istorija, arba Praktinès botanikos pradmenys“), išleistame 1806 m., Ž. E. Žiliberas aprašė XVIII a. pab. Lietuvos kaimą. Pasakodamas apie ligas, daktaras pabrèžè, kad lietuviai valstiečiai susirgę moka kentèti, atsiduodami gamtos gydomosioms galioms: „Patirtis juos išmokè atpažinti ligas ir suprasti, kurias iš jų galima gydyti, o kurių negalima. Pirmuoju atveju valstiečiai geria rūgštų gėrimą ir ramiai guli lovoje. Antruoju atveju jie laukia mirties be murmejjimų ir skundų. " [2] (Kursyvu pažymèta autoriaus - E. S. J.)

Jau senoveje suprasta, kad poilsis ir miegas yra gyvybiškai svarbūs, tokie patys reikšmingi kaip kvėpavimas, valgymas ir kitos organizmo funkcijos. Tačiau tik pastaraisiais dešimtmečiais buvo įrodyta, kad miegas - ne pasyvus, o aktyvus procesas, kurio metu atnaujinami smegenų ir viso organizmo energetiniai rezervai, reguliuojamos imuninès reakcijos, skatinama makromolekulių sintezė ir taisyklingas baltymų struktūrų susidarymas, ribojama oksidacinio streso sukelta ląstelių pažaida, vyksta informaci-

(C) Neurologijos seminarai, 2020. Open Access. This article is distributed under the terms of the Creative Commons Attribution 4.0 International License CC-BY 4.0 (http://creativecommons.org/licenses/by/4.0/), which permits unrestricted use, distribution, and reproduction in any medium, provided you give appropriate credit to the original author(s) and the source, provide a link to the Creative Commons license, and indicate if changes were made. 
jos perdirbimas, atranka, išsaugojimas ir kiti procesai. Per pastaruosius 30 metų moksliniuose tyrimuose taip pat nustatyta aiški sąsaja tarp imuninès sistemos reaktyvumo ir miego kokybès bei tai, kaip sutrikęs miegas neigiamai veikia imuninès sistemos funkcijas [3].

\section{VIRUSINĖS INFEKCIJOS SUKELIAMI MIEGO POKYČIAI}

Žmogaus organizmui susidūrus su infekcija, pasireiškia ūmios fazès atsakas: aktyvuojami biocheminiai procesai (sintetinami ūmios fazès baltymai, streso hormonai), aktyvuojama imuninė sistema, kinta sergančiojo fiziologinė reakcija (ligonis karščiuoja, padidejja kraujagyslių pralaidumas) ir elgesys (didejja mieguistumas, pablogèja apetitas).

Ūmios fazės atsaką sukelia baltymai citokinai: prouždegiminiai I klasès citokinai (interleukinas $1 \beta$ (IL-1 $\beta$ ), naviko nekrozès faktorius- $\alpha$ (TNF- $\alpha$ ), IL-6; šie citokinai tiesiogiai veikia ir miego procesą) ir priešuždegiminiai II klasès citokinai (interferonas- $\alpha$ (INF- $\alpha$ ), INF- $\beta$, IL-4, IL-10 ir kiti; šie citokinai taip pat gali moduliuoti miego procesą). Irodyta, kad infekcinio susirgimo metu, vykstant citokinu sukeltų biocheminių ir imuninių reakcijų kaskadai, kinta miego struktūra: padideja NREM (angl. non-rapid eye movement, lètojo) miego ir sumažeja REM (angl. rapid eye movement, greitų akių judesių arba paradoksinio) miego kiekis [4]. Taip pat įrodyta, kad prouždegiminiai I klasės citokinai IL-1 ir TNF- $\alpha$, susirgus infekcine arba autoimunine uždegimine liga, didina NREM miego kiekį, o šių citokinų inhibitoriai, tokie kaip anakinra (IL-1 receptoriaus antagonistas) ir etanerceptas (TNF- $\alpha$ inhibitorius), sumažina nuovargị ir mieguistumą reumatoidiniu artritu sergantiems ligoniams [4].

İdomu pažymèti, kad būtent infekcinio proceso sukeltas mieguistumas, kartu su kita neurologine simptomatika (hipokinezès, hiperkinezès, distonijos, oftalmoplegija, okulogirinès krizès ir kt.) ligoniams, XX a. pr. sirgusiems letarginiu encefalitu ${ }^{1}$, ir paskatino miego fiziologijos bei patofiziologijos tyrimus. Nors miegas beveik iki pat XX a. pr. buvo suvokiamas kaip pasyvus procesas, Konstantinas von Economo (1885-1975) vienas pirmųjų savo tyrimuose 1930 m. atrado sąsajas tarp pomirtinių pažeidimų ligonių, sirgusių letarginiu encefalitu, smegenyse ir specifinių miego struktūros pakitimų [5]. Mokslininkas nustatė, kad pažeidimai rostralinejje gumburo ir viduriniujuc smegenų jungties dalyje ligoniams sukeldavo nemigą, o pažeidimai, esantys kaudalinejje šios jungties dalyje, - patologinị mieguistumą [6]. Šis darbas taip pat leido suprasti, kad miegas yra aktyvus procesas, o už miego ir būdravimo ciklus yra atsakingos tam tikros sritys centrinèje nervų sistemoje (CNS).
Siekiant ịrodyti sisteminès virusinės infekcijos poveikị miegui, sukurtas vienos dažniausiai pasaulyje pasireiškiančių ligų sukèlejjų - gripo viruso - modelis. Šis modelis buvo tinkamas tuo, kad pradinèse gripo stadijose virusas dauginasi vien kvėpavimo takuose ir nesukelia struktūrinių pakitimų CNS. Nustatyta, kad maži gripo viruso kiekiai žmogaus organizme didina mieguistumą ir sutrikdo kognityvines funkcijas, ligoniui net nepradejus karščiuoti. Vadinamajji „peršalimą" sukeliančių rinovirusų infekcija sveikiems savanoriams taip pat buvo susijusi su bendru miego kiekio padidejimu [7]. Akivaizdu, kad padidèjęs mieguistumas NREM miego sąskaita yra ūmios fazès atsako ị infekciją dalis. Tačiau ar yra žinoma, kaip miego stoka daro įtaką žmogaus imuninėms funkcijoms?

\section{MIEGO STOKOS ITAKA IMUNINĖMS FUNKCIJOMS}

Tyrimuose su 12 žinduolių rūšiu įrodyta, kad pakankamas miego kiekis gerina imunines funkcijas, didina leukocitų kiekị kraujyje, ir tokie gyvūnai tampa mažiau imlūs parazitinėms infekcijoms [8]. Šiuolaikiniam žmogui, gyvenančiam postmodernioje, vartotojiškoje, „24 val. per parą, 7 dienų per savaitę“" visuomenẻje, lètinị miego trūkumą dažniausiai sukelia pamaininio darbo režimas. Pamaininị darbą dirbančių asmenų populiacijos tyrimai įrodè, kad šioje grupejje infekcinių susirgimų dažnis ${ }^{2}$ yra reikšmingai didesnis nei kitų darbuotojų, nedirbančių pamaininio darbo [9]. Taip pat nustatyta, kad asmenys, miegantys mažiau nei 7 val. per nakti arba kurių miego efektyvumas yra mažesnis nei $92 \%$, dažniau serga viršutinėmis kvėpavimo takų ligomis nei ilgiau miegantys individai [10].

Kita miego trukmės ir imuninès sistemos reaktyvumo tyrimų grupè analizavo miego stokos įtaką vakcinacijos efektyvumui. Irodyta, kad tiriamiesiems asmenims, kuriems 4 naktis iki gripo vakcinos buvo sutrumpintas nakties miegas iki 4 val., o po skiepų 2 dienas miego kiekis taip pat buvo sumažintas, 10 dieną, ištyrus po vakcinacijos pasigaminusių antikūnų titrus, jie siekė tik $50 \%$ kontrolinès grupès (kuriems buvo leista miegoti 8 val. per nakti) antikūnų titru [11]. Kitame tyrime asmenims, po vakcinacijos nuo hepatito A viruso, miego deprivacija buvo sutrumpinta tik iki vienos nakties. Praejjus 4 savaitėms, antikūnų titrai miego deprivacijos grupès tiriamiesiems siekè vos $50 \%$ titrų, nustatytų kontrolinès grupès asmenims [12]. Irodyta, kad bent viena miego deprivacijos naktis mažiausiai vieneriems metams sumažino antigenams specifiškų T helperių ir antigenams specifiškų antikūnų kiekị kraujyje skiepytiems asmenims [13]. Vadinasi, miego trūkumas veikia kaip reikšmingas funkcinę imunosupresiją sukeliantis faktorius.

\footnotetext{
${ }^{1}$ Ilgą laiką manyta, kad von Economo aprašytas letarginis encefalitas buvo sukeltas $1918 \mathrm{~m}$. siautusio ispaniškojo gripo pandemijos, tačiau vėlesni tyrimai patvirtino, kad liga pasireiške dar gerokai prieš gripo pandemiją (nuo $1916 \mathrm{~m}$.) ir veikiausiai buvo autoimuninė streptokokinès infekcijos, pažeidusios pamatinius mazgus CNS, komplikacija [21]. Be to, išsaugotuose ligonių, sirgusių letarginiu encefalitu, galvos smegenų preparatuose vèlesniuose tyrimuose nebuvo rasta gripo viruso RNR [5].

${ }^{2}$ Be to, pamaininį darbą dirbančių asmenų populiacijoje pastebėta reikšmingai didesnė autoịvykių rizika, padidèjusi rizika susirgti krūties vèžiu (nuo 36 iki 60 \%), dvylikapirštès žarnos opalige, širdies ir kraujagyslių ligomis bei kt. [22].
} 


\section{MIEGO, SĄMONĖS SUTRIKIMAI IR COVID-19}

Daliai ligonių (15\%), sirgusių SARS-CoV 2 (angl. severe acute respiratory syndrome coronavirus 2 , sunkaus ūminio respiracinio sindromo koronaviruso-2) sukeltu COVID-19 ir gydytu Uhano mieste Kinijoje, pasireiškẻ ùminiai miego ir sąmonès sutrikimo sindromai - somnolencija, sumišimas, delyras, stuporas ir koma [14]. Manoma, kad delyrinę simptomatiką ir miego sutrikimus sukèlè su SARS-CoV 2 susiję neurotransmiterių pusiausvyros sutrikimai, prouždegiminių citokinų gamyba, audinių hipoksija ir miego deprivacija [15]. Ligonių, sirgusių COVID-19, kuriems pasireiškè neurologinès komplikacijos (galvos smegenų infarktas, hemoragijos, traukuliai, sąmonės sutrikimai, griaučių raumenų pažeidimas su padidejjusia kreatinfosfokinazès (KFK) ir laktatdehidrogenazès (LDH) koncentracija serume), po mirties atliktose autopsijose nustatyta smegenų edema, hiperemija ir neuronų degeneracija. Manoma, kad SARS-CoV 2 patenka ị likvorą ir galvos smegenų audinį panašiai kaip ir kiti koronavirusai ar respiraciniai virusai - hematogeninès diseminacijos būdu arba retrogradiškai per nervus [14].

Nors ligoniams, sergantiems COVID-19, skiriamas nespecifinis gydymas priešmaliariniais, priešvirusiniais preparatais, kortikosteroidais, oksigenoterapija, sunkesniais atvejais - dirbtine plaučių ventiliacija (DPV), specifinis COVID-19 gydymas šiuo metu dar nèra atrastas. Anksčiau, prieš COVID-19 pandemiją vykusiuose tyrimuose buvo nustatyta, kad melatonino ir melatonino receptorių agonistų ${ }^{3}$ skyrimas ligoniams, gydomiems reanimacijos ir intensyviosios terapijos skyriuose (RITS), sumažino šių ligonių hospitalizacijos RITS trukmę, taip pat delyro išsivystymo riziką ir pagerino miegą [16]. Kadangi melatoninas yra daug saugesnis vaistas nei benzodiazepinai ir antipsichotikai, ypač vyresnio amžiaus asmenims, kuriems RITS neretai ir taip taikoma polifarmakoterapija, siūloma melatoniną ar jo receptorių (MT1, MT2) agonistus skirti kaip pirmo pasirinkimo vaistus delyrui bei miego ir budrumo ciklo sutrikimams gydyti arba šių susirgimų profilaktikai [15]. Taip pat verta prisiminti ir tuos tyrimus, kurie ịrodè melatonino ir melatonino receptorių agonistų priešuždegiminį, antioksidacinį, imunitetą stiprinanti poveikị ligoniams, sirgusiems virusinès ar bakterinès infekcijos sukeltu ūminiu respiracinio distreso sindro$\mathrm{mu}$ [17].

Naujausioje literatūroje nurodoma, kad RITS net kritiškai sunkiems ligoniams yra pakankamai saugu skirti melatonino dozes, siekiančias $10 \mathrm{mg}$ ir daugiau. Melatoniną rekomenduojama skirti ligoniams, kurie gydomi dèl COVID-19 ir kuriems pasireiškia cirkadinio ritmo sutrikimai bei ūminiai sąmonès sutrikimo (sumišimas, delyras ir kt.) sindromai. Manoma, kad didelès melatonino dozės ga- li apsaugoti ligonius net nuo „citokinų audros“, kuri pasireiškia sergant COVID-19, tačiau tam įrodyti reikalingi papildomi tyrimai. Tyrejjai tvirtina, kad gydymas melatoninu gali būti veiksmingas ligoniams, sergantiems ne tik COVID-19 sukeltomis neurologinėmis komplikacijomis, bet, kaip papildomas gydymas, ir COVID-19 sukelta pneumonija bei ūmiu respiracinio distreso sindromu [18].

\section{COVID-19 GRÉSME், KARANTINAS IR SU JUO SUSIJE MIEGO SUTRIKIMAI}

Kognityvinès ir elgesio terapijos, skirtos nemigai (KET-N), akademijos darbo grupè $2020 \mathrm{~m}$. balandžio mènesị miego medicinai skirtame žurnale Journal of Sleep Research paskelbė straipsnị, kuriame ịvardijo pagrindines miego problemas, patiriamas COVID-19 pandemijos ir karantino metu, pateike rekomendacijas gyventojams ir sveikatos priežiūros specialistams [19]. Pasak autorių, dèl COVID-19 pandemijos ir paskelbto karantino, didžioji gyventojų dalis susiduria su pasikeitusio gyvenimo iššūkiais ir sunkumais kasdienybėje: nuotolinio darbo, vaiku mokymo iš namų ir šeimos poreikių derinimo, sumažejusio socialinio bendravimo, vienatvès, nežinomybès dèl ateities, susirūpinimo savo ir artimųjų sveikata, neigiamos, gąsdinančios su COVID-19 susijusios informacijos srauto žiniasklaidoje, karantino metu sumažèjusių darbo krūvių bei darbo užmokesčio, prarasto darbo ir pan. Gyventojai taip pat susiduria ir su miego problemomis, kurias gali sukelti tiek patiriamas stresas, tiek cirkadinio ritmo disbalansas dèl sumažejusios saulès šviesos, būnant uždarose patalpose, sumažèjusio fizinio aktyvumo, miego higienos principų pažeidimo, besaikio TV žiūrèjimo prieš miegą ir pan. Ypač didelị stresą, pasak straipsnio autorių, šiuo metu patiria motinos, auginančios kūdikius ir mažamečius vaikus, bei ligonių ar neigaliujų globejjai. Kokybiškas ir pakankamas miegas šioje situacijoje yra svarbiausias veiksnys, reguliuojantis mūsų elgesị ir emocijas [19].

Pasak KET-N akademijos darbo grupès narių, lètinei nemigai gydyti karantino laikotarpiu pirmiausia reikètų rekomenduoti KET-N, kaip pirmo pasirinkimo gydymo metodą, teikiant pirmenybę nuotolinėms psichoterapeutu konsultacijoms. Antro pasirinkimo nemigos gydymas trumpalaikis (dažniausiai iki 4 sav. trukmès) benzodiazepinų (BZD) grupès vaistu arba BZD receptorių agonistu kursas. Jei paciento nemiga yra susijusi su nuotaikos ar nerimo sutrikimais, vietoje BZD galima skirti seduojančius antidepresantus. Ūminei nemigai (sukeltai išorinių stresorių ar namų izoliacijos) gydyti galima skirti trumpalaiki BZD grupès vaistų arba BZD receptorių agonistų kursą [19]. KET-N akademijos darbo grupès miego higienos re-

\footnotetext{
${ }^{3}$ Lietuvoje registruotas agomelatinas yra ne tik MT1/MT2 receptorių agonistas, gerinantis miegą, stabilizuojantis dienos ir nakties ritmą, bet ir 5-HT2C receptorių antagonistas (dẻl 5-HT2C receptorių antagonizmo agomelatinas veikia antidepresiškai, sustiprindamas dopamino ir norepinefrino išsiskyrimą smegenų prefrontalinėje žievejje) [23, 24]. Lietuvoje melatonino preparatai šiuo metu yra prieinami tiek kaip receptiniai vaistai, tiek kaip maisto papildai [25]. Kitas MT1/MT2 receptorių agonistas ramelteonas Lietuvoje nėra registruotas.
} 


\section{1 lentelè. Miego higienos rekomendacijos gyventojams}

\begin{tabular}{|c|c|}
\hline Rekomendacija & Paaiškinimas \\
\hline $\begin{array}{l}\text { 1. Kiekvieną vakarą gulkitės, o } \\
\text { rytą - kelkitès tuo pačiu metu }\end{array}$ & $\begin{array}{l}\text { Stenkitès kiekvieną vakarą eiti miegoti tuo pačiu metu, o rytais - keltis tuo pačiu metu. } \\
\text { Reguliarus miego režimas miegą padaro efektyvesni. }\end{array}$ \\
\hline $\begin{array}{l}\text { 2. Suplanuokite kelias } 15 \text { min. } \\
\text { trukmės pertraukas tarp darbų }\end{array}$ & $\begin{array}{l}\text { Trumpų poilsio ir savirefleksijos pertraukų metu stenkitės apmąstyti sunkesnes situacijas, su ar- } \\
\text { timaisiais aptarti stresą sukèlusias mintis. Tą padarius dieną, didesnè tikimybė, kad nakties } \\
\text { miegas bus ramesnis. }\end{array}$ \\
\hline $\begin{array}{l}\text { 3. Naudokitės žiniasklaidos } \\
\text { priemonėmis saikingai }\end{array}$ & $\begin{array}{l}\text { Rekomenduojama naudotis žiniasklaidos priemonėmis ir socialiniais tinklais, kai norite } \\
\text { pabendrauti su toliau gyvenančiais artimaisiais ar draugais, tačiau stenkitės riboti neigiamos, } \\
\text { stresą sukeliančios informacijos (ypač apie COVID-19 pandemiją) srautą. Nesineškite } \\
\text { kompiuterių ar skaityklių ị miegamajị, nes elektroninių prietaisų skleidžiama šviesa blokuoja } \\
\text { melatonino išsiskyrimą epifizėje ir blogina miegą naktị. }\end{array}$ \\
\hline $\begin{array}{l}\text { 4. Ribokite vaikų laiką, pralei- } \\
\text { džiamą prie TV, kompiuterių } \\
\text { ar išmaniųjų telefonų }\end{array}$ & $\begin{array}{l}\text { Nors kompiuteriai - svarbi priemonė vaikų nuotoliniam ugdymui karantino sąlygomis, } \\
\text { nerekomenduojama žiūretti TV, naudotis kompiuteriais ar išmaniaisiais telefonais po pietų ir } \\
\text { vakare. Neleiskite jų vaikams neštis į lovas! }\end{array}$ \\
\hline 5. Mankštinkitės & $\begin{array}{l}\text { Reguliari mankšta rytais arba ankstyvą popietę, fizinis aktyvumas dieną pagerina gilų miegą } \\
\text { naktį. Tačiau fizinis aktyvumas, likus kelioms valandoms iki miego, gali trukdyti užmigti. }\end{array}$ \\
\hline $\begin{array}{l}\text { 6. Stenkitès būti apšviesti } \\
\text { natūralios saulès šviesos dieną }\end{array}$ & $\begin{array}{l}\text { Natūrali dienos šviesa, ypač rytais, yra labai svarbi cirkadinio ritmo reguliavimui. Jei to padary- } \\
\text { ti neịmanoma, stenkitès dieną apšviesti kambarius, atitraukdami užuolaidas arba ijungdami } \\
\text { šviesas. Vakare šviesa turi būti blankesnè. Naktị jūsų miegamajame turètų būti tamsu. }\end{array}$ \\
\hline 7. Koreguokite mitybą & $\begin{array}{l}\text { Karantino metu, sumažejus fiziniam aktyvumui, reikètų valgyti mažiau. Be to, sunkus maistas } \\
\text { vėlyvą vakarą gali trukdyti užmigti, todèl rekomenduojama paskutinị kartą valgyti ne vèliau nei } \\
2 \text { val. iki miego. }\end{array}$ \\
\hline 8. Atsisakykite žalingų ịpročių & $\begin{array}{l}\text { Kava, arbata ir kiti gėrimai bei maistas, kurių sudètyje yra kofeino, veikiančio kaip } \\
\text { stimuliatorius, gali trikdyti užmigti, todėl rekomenduojama nevartoti kofeino iki nakties miego } \\
\text { likus 4-6 valandoms, taip pat reikètų mažinti kofeino turinčių gèrimų vartojimą dieną. Nors } \\
\text { alkoholis pagreitina užmigimą, tačiau sutrikdo miego struktūrą - dèl šios priežasties alkoholis } \\
\text { nèra geras būdas, siekiant visaverčio nakties miego. Cigaretės ir kiti nikotino turintys produktai } \\
\text { yra stimuliatoriai, jų turėtų būti vengiama, ypač vakare prieš miegą ir prabudus naktį. }\end{array}$ \\
\hline $\begin{array}{l}\text { 9. Dalinkitės kasdienės veiklos } \\
\text { darbais su kitais šeimos nariais }\end{array}$ & $\begin{array}{l}\text { Pastebėta, kad šeimose, auginančiose mažamečius vaikus, dažniausiai pervargsta ir „perdega“ } \\
\text { moterys. Todèl būtina kasdienės veiklos darbais (vaikų priežiūra, namų mokymu, buities } \\
\text { darbais, valgio gaminimu ir kt.), jei įmanoma, dalintis su partneriu ir kitais šeimos nariais. }\end{array}$ \\
\hline $\begin{array}{l}\text { 10. Nemiegokite tame } \\
\text { pačiame kambaryje su vaiku }\end{array}$ & $\begin{array}{l}\text { Rekomenduojama tėvams nemiegoti tame pačiame kambaryje su vaikais. Vaikų ir tėvų } \\
\text { miegojimas kartu blogina miego kokybę. }\end{array}$ \\
\hline $\begin{array}{l}\text { 11. Sukurkite ryšį tarp } \\
\text { miegamojo patalpos ir greito } \\
\text { užmigimo }\end{array}$ & $\begin{array}{l}\text { Siekiant sukurti ryši tarp miegamojo patalpos ir greito užmigimo, reikètų laikytis šių taisyklių: } \\
\text { a) lovą reikètų naudoti tik intymiam bendravimui ir miegui, nereikètų lovoje skaityti, } \\
\text { valgyti, žiūrėti TV ar užsiimti kita veikla; } \\
\text { b) reikètų gultis tik tada, kai norisi miego; } \\
\text { c) jei negalite užmigti } 10-20 \text { minučių, turètumète atsikelti iš lovos, išeiti iš miegamojo ir } \\
\text { vèl gultis tik tada, kai norite miego; } \\
\text { d) keltis rytais tuo pačiu laiku ir vengti miego dieną. }\end{array}$ \\
\hline $\begin{array}{l}\text { 12. Sukurkite tinkamą miegui } \\
\text { aplinką }\end{array}$ & $\begin{array}{l}\text { Nustatyta, kad geriau užmiegama kiek vėsesnėje, gerai išvėdintoje patalpoje. Rekomenduojama } \\
\text { vengti šviesos ir triukšmo. Ruoškitès miegui atlikdami atpalaiduojančius ritualus (karšta vonia, } \\
\text { ramios literatūros skaitymas ar užsiėmimas kita streso nesukeliančia veikla). }\end{array}$ \\
\hline
\end{tabular}

Parengta pagal Altena E, Baglioni C, Espie CA, Ellis J, GavriloffD, Holzinger B, et al. Dealing with sleep problems during home confinement due to the COVID-19 outbreak: practical recommendations from a task force of the European CBT-I Academy. Journal of Sleep Research 2020; e13052 [19] ir Edinger JD, Leggett MK, Carney CE, Manber R. Psychological and behavioral treatments for insomnia II: implementation and specific populations. In: Kryger M, Roth T, Dement WC, eds. Principles and practice of sleep medicine. Philadelphia: Elsevier, 2017; p. 814-31 [20].

komendacijos gyventojams ir sveikatos priežiūros specialistams COVID-19 pandemijos metu pateiktos 1 ir 2 lentelèse.

\section{IŠVADOS}

1. Jau senoveje žinota, kad poilsis ir miegas yra gyvybiškai svarbūs, tokie pat reikšmingi kaip kvėpavimas, valgymas ir kitos organizmo funkcijos. Per pastaruosius
30 metų nustatyta aiški sąsaja tarp pakankamo, kokybiško miego ir darnaus imuninès sistemos funkcionavimo.

2. Padidèjęs mieguistumas NREM miego sąskaita - tai natūrali ūmios fazès atsako ị virusinę infekciją dalis, kurią moduliuoja baltymai citokinai.

3. Irodyta, kad miego trūkumas veikia kaip reikšmingas funkcinę imunosupresiją sukeliantis faktorius.

4. Naujausioje mokslinèje literatūroje skelbiama, kad melatonino ar melatonino receptorių agonistuc skyri- 


\section{2 lentelè. Miego higienos rekomendacijos sveikatos priežiūros specialistams}

\begin{tabular}{|c|c|}
\hline Rekomendacija & Paaiškinimas \\
\hline $\begin{array}{l}\text { 1. Suplanuokite kasdienius } \\
\text { pokalbius su savo komandos } \\
\text { arba šeimos nariais }\end{array}$ & $\begin{array}{l}\text { Suplanuokite pokalbius su savo komandos nariais (kuriais pasitikite), pokalbių metu jūs } \\
\text { galėtumėte papasakoti apie darbo metu patirtas problemas ir iššūkius. İvardijus ir išsprendus } \\
\text { problemas dieną, didesnè tikimybė, kad nakties miegas bus ramesnis. }\end{array}$ \\
\hline $\begin{array}{l}\text { 2. Laisvalaikiu užsiimkite } \\
\text { malonia veikla }\end{array}$ & $\begin{array}{l}\text { Laisvu nuo darbo metu stenkitès nutolti nuo su savo profesija susijusių problemų, užsiimkite } \\
\text { malonia, įtraukiančia veikla. }\end{array}$ \\
\hline $\begin{array}{l}\text { 3. Ribokite neigiamos } \\
\text { informacijos srautą }\end{array}$ & $\begin{array}{l}\text { Kiek ịmanoma stenkitès riboti neigiamos, stresą sukeliančios informacijos apie COVID-19 } \\
\text { pandemiją srautą, jei tai tiesiogiai nèra susiję su jūsų darbo specifika. }\end{array}$ \\
\hline 4. Laisvalaikiu mankštinkitès & $\begin{array}{l}\text { Nepamirškite, kad reguliari mankšta ir fizinis aktyvumas dieną pagerina gilų miegą naktị. } \\
\text { Tačiau mankšta prieš pat miegą gali trukdyti užmigti. }\end{array}$ \\
\hline $\begin{array}{l}\text { 5. Stenkitès būti apšviesti } \\
\text { natūralios saulès šviesos dieną }\end{array}$ & $\begin{array}{l}\text { Natūrali dienos šviesa, ypač rytais, yra labai svarbi cirkadiniam ritmui reguliuoti. Jei to padaryti } \\
\text { neịmanoma, stenkitės dienos metu savo darbo vietoje ijungti šviesas, išskyrus tame kambaryje, } \\
\text { kuriame ilsėsitės naktị. Vakarais ir naktimis jūsų darbo vietoje šviesa turi būti blankesnè. }\end{array}$ \\
\hline $\begin{array}{l}\text { 6. Prieš miegą stenkitès užsiim- } \\
\text { ti streso nesukeliančia veikla }\end{array}$ & $\begin{array}{l}\text { Jei tai yra ịmanoma, ruoškitès miegui atlikdami atpalaiduojančius ritualus (pvz., ramios } \\
\text { literatūros skaitymas ir kt.). }\end{array}$ \\
\hline 7. Reguliariai maitinkitės & $\begin{array}{l}\text { Rekomenduojamas lengvas maistas, jei įmanoma - reguliariais laiko tarpais. Prieš nakties } \\
\text { miegą rekomenduojama neprisivalgyti, nes virškinimo procesas blogins miego kokybę. }\end{array}$ \\
\hline $\begin{array}{l}\text { 8. Jei jaučiate simptomus, } \\
\text { susijusius su nuovargiu ir } \\
\text { irzlumu, nusnūskite }\end{array}$ & $\begin{array}{l}\text { Jei darbo metu patiriate simptomus, susijusius su dideliu nuovargiu, jei jaučiate, kad sunku susikon- } \\
\text { centruoti ir galite suklysti, jaučiate irzlumą ir sunku suvaldyti emocijas, apie tai informuokite savo } \\
\text { komandos narius ir nusnūskite. Net trumpas nusnūdimas gali pagerinti jūsų savijautą ir darbingumą. }\end{array}$ \\
\hline $\begin{array}{l}\text { 9. Po ilgos darbo pamainos } \\
\text { venkite vairuoti }\end{array}$ & $\begin{array}{l}\text { Po ilgos darbo pamainos venkite pats vairuoti dèl didelès autoịvykių rizikos. Geriau namo } \\
\text { vykite viešuoju transportu arba taksi. }\end{array}$ \\
\hline
\end{tabular}

Parengta pagal Altena E, Baglioni C, Espie CA, Ellis J, Gavriloff D, Holzinger B, et al. Dealing with sleep problems during home confinement due to the COVID-19 outbreak: practical recommendations from a task force of the European CBT-I Academy. Journal of Sleep Research 2020; e13052 [19]

mas ligoniams, gydomiems reanimacijos ir intensyviosios terapijos skyriuose dèl COVID-19, gali pagerinti šių ligonių miegą, sumažinti ūmių sąmonès sutrikimų sindromų išsivystymo riziką, apsaugoti nuo „citokinų audros" ir tolesnio kvėpavimo sistemos pažeidimo.

5. Didžioji gyventojų dalis dèl COVID-19 pandemijos ir paskelbto karantino susiduria su pasikeitusio gyvenimo iššūkiais, sunkumais kasdienybejje ir miego problemomis. Kokybiškas, pakankamas miegas ir miego higienos rekomendacijų laikymasis šioje sudetingoje situacijoje yra svarbiausias veiksnys, reguliuojantis mūsų elgesị, emocijas ir lemiantis tinkamas imuninès sistemos funkcijas.

\section{Literatūra}

1. Parent A. Prancūzų gydytojų medicinos mokslo paveldas Lietuvoje XVIII a. paskutiniame ketvirtyje (Jeanas-Emmanuelis Gilibert'as, Nicolas Regnier, Jacques'as Briotet). In: Šmigelskytė-Stukienė R, ed. XVIII amžiaus studijos, T 2: Lietuvos Didžioji Kunigaikštystė. Valstybė. Kultūra. Edukacija. Vilnius: Lietuvos istorijos institutas, 2015; 122-46.

2. Parent A. Gydytojo botaniko Žano Emanuelio Žilibero pastebejimai apie XVIII a. pabaigos lietuvių valstietijos gyvenimą. Liaudies kultūra 2014; 3: 44-52.

3. Kryger M, Roth T, Dement WC, eds. Principles and practice of sleep medicine. $6^{\text {th }}$ ed. Philadelphia: Elsevier, 2017.

4. Opp MR, Krueger JM. Sleep and host defense. In: Kryger M, Roth T, Dement WC, eds. Principles and practice of sleep medicine. $6^{\text {th }}$ ed. Philadelphia: Elsevier, 2017; 193-201. https://doi.org/10.1016/B978-0-323-24288-2.00019-2
5. Lanska DJ. The history of movement disorders. Handb Clin Neurol 2010; 95: 501-46. https://doi.org/10.1016/S00729752(08)02133-7

6. von Economo C. Sleep as a problem of localization. J Nerv Ment Dis 1930; 71: 249-59. https://doi.org/10.1097/ 00005053-193003000-00001

7. Drake CL, Roehrs TA, Royer H, Koshorek G, Turner RB, Roth T. Effects of an experimentally induced rhinovirus cold on sleep, performance, and daytime alertness. Physiol Behav 2000; 71: 75-81. https://doi.org/10.1016/S00319384(00)00322-X

8. Preston BT, Capellini I, McNamara P, Barton RA, Nunn CL. Parasite resistance and the adaptive significance of sleep. BMC Evol Biol 2009; 9: 7. https://doi.org/10.1186/14712148-9-7

9. Mohren DC, Jansen NW, Kant IJ, Galama J, van den Brandt PA, Swaen GM. Prevalence of common infections among employees in different work schedules. J Occup Environ Med 2002; 44: 1003-11. https://doi.org/10.1097/ 00043764-200211000-00005

10. Cohen S, Doyle WJ, Alper CM, Janicki-Deverts D, Turner RB. Sleep habits and susceptibility to the common cold. Arch Intern Med 2009; 169: 62-7. https://doi.org/ 10.1001/archinternmed.2008.505

11. Spiegel K, Sheridan JF, van Cauter E. Effect of sleep deprivation on response to immunization. JAMA 2002; 288: 1471-2. https://doi.org/10.1001/jama.288.12.1469

12. Lange T, Perras B, Fehm HL, Born J. Sleep enhances the human antibody response to hepatitis A vaccination. Psychosom Med 2003; 5: 831-5. https://doi.org/10.1097/ 01.PSY.0000091382.61178.F1

13. Lange T, Dimitrov S, Bollinger T, Diekelmann S, Born J. Sleep after vaccination boosts immunological memory. J 
Immunol 2001; 187: 283-90. https://doi.org/10.4049/ jimmunol.1100015

14. Mao L, Jin H, Wang M, Hu Y, Chen S, He Q, et al. Neurologic manifestations of hospitalized patients with coronavirus disease 2019 in Wuhan, China. JAMA Neurol 2020 77(6): 683-90. https://doi.org/10.1001/jamaneurol. 2020.1127

15. Zambrelli E, Canevini M, Gambini O, D'Agostino A. Delirium and sleep disturbances in COVID-19: a possible role for melatonin in hospitalized patients? Sleep Med 2020; 70: 111. https://doi.org/10.1016/j.sleep.2020.04.006

16. Zhang Q, Gao F, Zhang S, Sun W, Li Z. Prophylactic use of exogenous melatonin and melatonin receptor agonists to improve sleep and delirium in the intensive care units: a systematic review and meta-analysis of randomized controlled trials. Sleep Breath 2019; 23(4): 1059-70. https://doi.org/ 10.1007/s11325-019-01831-5

17. Wu GC, Peng CK, Liao WI, Pao HP, Huang KL, Chu SJ. Melatonin receptor agonist protects against acute lung injury induced by ventilator through up-regulation of IL-10 production. Respir Res 2020; 21(1): 65. https://doi.org/10.1186/ s12931-020-1325-2

18. Zhang R, Wang X, Ni L, Di X, Ma B, Niu S, et al. COVID-19: Melatonin as a potential adjuvant treatment. Life Sci 2020; 250: 117583. https://doi.org/10.1016/j.lfs.2020.117583

19. Altena E, Baglioni C, Espie CA, Ellis J, Gavriloff D, Holzinger B, et al. Dealing with sleep problems during home confinement due to the COVID-19 outbreak: practical recommendations from a task force of the European CBT-I Academy. J Sleep Res 2020; e13052. https://doi.org/ 10.1111/jsr.13052

20. Edinger JD, Leggett MK, Carney CE, Manber R. Psychological and behavioral treatments for insomnia II: implementation and specific populations. In: Kryger M, Roth T, Dement WC, eds. Principles and practice of sleep medicine. $6^{\text {th }}$ ed. Philadelphia: Elsevier, 2017; 814-31. https://doi.org/ 10.1016/B978-0-323-24288-2.00086-6

21. Dale RC, Church AJ, Surtees RAH, Lees AJ, Adcock JE, Harding B, et al. Encephalitis lethargica syndrome: 20 new cases and evidence of basal ganglia autoimmunity. Brain 2004; 127: 21-33. https://doi.org/10.1093/brain/awh008

22. Drake CL, Wright KP. Shift work, shift-work disorder, and jet lag. In: Kryger M, Roth T, Dement WC, eds. Principles and practice of sleep medicine. $6^{\text {th }}$ ed. Philadelphia: Elsevier, 2017; 715-25. https://doi.org/10.1016/B978-0323-24288-2.00075-1

23. Šiurkutė A. Klinikinès psichofarmakoterapijos pagrindai. Vilnius: Vilniaus universiteto leidykla, 2018.

24. Valstybinè vaistu kontrolès tarnyba. Vaistu registracija. Agomelatinas. Prieiga per internetą: https://vapris.vvkt.lt/ vvkt-web/public/medications/view/27118 [Žiūrèta 2020-04-20].

25. Valstybinė vaistų kontrolès tarnyba. Vaistų registracija. Melatoninas. Prieiga per internetą: https://vapris.vvkt.lt/ vvkt-web/public/medications/view/28012 [Žiūrèta 2020-04-20].

\section{E. Sakalauskaitė-Juodeikienė}

\section{COVID-19 INFECTION, QUARANTINE, AND SLEEP DISORDERS: LITERATURE REVIEW}

\section{Summary}

It has been known since ancient times that rest and sleep are vital, as are breathing, eating, and other bodily functions. Over the last 30 years, a clear link has been established between adequate sleep and the proper functioning of the immune system. In this article, the author reviews sleep changes caused by viral infection and provides evidence that sleep deprivation acts as a significant factor in functional immunosuppression. The author reviews recent scientific literature suggesting that the administration of melatonin and melatonin receptor agonists for patients with COVID-19 infection treated in the intensive care unit can reduce prevalence of delirium and improve sleep quality, protect patients from "cytokine storm" and improve acute lung injury. Finally, it will be explained how adequate sleep and adherence to sleep hygiene recommendations in this difficult situation can be one of the most important factors regulating our behaviour and emotions and guaranteeing the proper functions of the immune system.

Keywords: sleep disorders, viral infection, acute phase response, COVID-19, melatonin.

Gauta:

Priimta spaudai:

20200423 